\title{
Differences in Blood Type and the Effects of Essential Oil Inhalation on the Autonomic Nervous System
}

\author{
Seon-Hee $\mathrm{Heo}^{1}$, Jun-Young Shim² ${ }^{2}$ Seongmo Yoo ${ }^{2 \star}$ \\ ${ }^{1}$ Neuro-Aromachology Institute, Incheon, Korea \\ ${ }^{2}$ Department of Brain Education, University of Brain Education, Cheonan-si, Chungcheongnam-do, Korea
}

\begin{abstract}
"Corresponding author: Seongmo Yoo, Department of Brain Education, University of Brain Education, 284-31 Gyocheonjisangil, Jisan-ri, Mokcheon-eup, Dongnam-gu, Cheonan-si, Chungcheongnam-do 31228, Korea
\end{abstract}

Tel.: +82 415292679

Fax: +82 415292679

Email: syoo@ube.ac.kr

Received February 23, 2017

Revised May 11, 2017

Accepted May 17, 2017

Published September 30, 2017

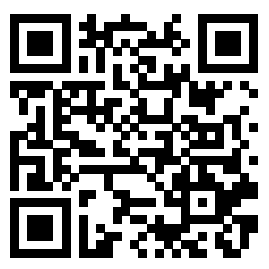

\begin{abstract}
Purpose: This study aims to compare the effects of inhalation of blended aroma essential oils on autonomic nervous system (ANS) according to blood type (BT). Methods: Peppermint, rosemary, eucalyptus, pine, and lemon essentials oils were mixed in the ratio of 12:4:2:1:1, respectively. In total, 32 middle-aged women inhaled the blended aroma oil for $28 \mathrm{~min}$. Heart rate variability (HRV) was measured and an electroencephalogram (EEG) was conducted before; immediately after; and 4, 8, 12, 16, 20, and 24 min after essential oil inhalation. Results: Analysis revealed significant differences in $\mathrm{BT}$-time interaction for average heart rate (HR), low frequency/high frequency activity ratio (LF/HF), and relative alpha. Conclusion: The effects of aroma essential oil inhalation on ANS are dependent on the duration of inhalation and individual BT.
\end{abstract}

Keywords: Electroencephalogram, Heart rate variability, Essential oils, Autonomic nervous system, Blood type

\section{Introduction}

아로마테라피는 식물에서 추출한 에센셜오일의 치유적 성분을 이용한 대체요법의 일종으로 신체적, 정신적 건강 유지와 증진에 도움이 되는 것으로 알려져 있으며(Buckle, 1999), 보건, 의료, 미 용 분야를 비롯한 전문분야는 물론 일상생활에서도 마사지법, 음 용법, 흡입법 등의 형태로 널리 활용되고 있다(Buckle, 1999; HeO $\&$ Yoo, 2016). 아로마테라피는 부작용이 거의 없고 갱년기조절, 불 안조절, 비만조절, 우울조절, 스트레스조절, 수면조절, 지질조절, 통증조절, 피로조절, 혈압조절 등에 효과적인 것으로 알려져 있으 며(Jeon \& Woo, 2014), 신체와 심리의 항상성 유지, 부조화 개선, 행복감 향상, 면역기능 강화에도 효과가 있는 것으로 알려져 있다 (Buckley, 2002).

아로마 에센셜오일은 자율신경계(autonomic nervous system,
$\mathrm{ANS})$ 의 균형에 영향을 미치는 것으로 알려져 있으며, 에센셜 오일 흡입으로 인한 ANS의 변화 양상은 심박변이도(heart rate variability, HRV)와 뇌파(electroencephalogram, EEG) 등과 같은 생리학적인 척도를 사용하여 측정할 수 있다(Jung \& Lim, 2016). 라벤더 향의 흡입은 심장박동수와 혈압의 측면에서 진정효과가 있 는 것으로 알려져 있으며(Dunn et al., 1995), 라벤더와 카모마일 흡 입은 부교감신경의 활성화와 $\mathrm{ANS}$ 균형도 유지에 도움을 주는 것으 로 알려져 있고(Shin et al., 2004), 로즈마리와 라벤더 에센셜오일 은 알파파의 활성화를 통하여 긴장을 완화시키는 것으로 알려져 있 고(Diego et al., 1998), 장미 향은 알파파를 증가시켜 뇌기능에 긍정 적인 영향을 미치는 것으로 알려져 있다(Iijima et al., 2009). 또한 로만 카모마일 흡입은 부교감신경의 활성도와 스트레스 저항력을 증가시키고, 상대 알파파의 증가와 상대 베타파의 감소를 통하여 심리적 안정을 유발하는 것으로 알려져 있다(Jung \& Lim, 2016). 
에센셜오일 흡입으로 인해 알파파가 증가하는 이유는 테르핀 (terpene)과 같은 항스트레스 물질이 코로 흡입되어 후각수용체를 거친 전기적 신호가 전두엽 피질에 도달하여 알파파를 활성화시 키는 것으로 추정된다(Masago et al., 2000). 뇌의 전두엽, 두정 엽, 측두엽 부위에서 발생하는 알파파는 부교감신경의 활성을 유 도하는 것으로 알려져 있으며(Doufesh et al., 2014; Sayorwan et al., 2012), 알파파 활성은 교감신경 활성도(low frequency, LF), 교감신경 활성도와 부교감신경 활성도의 비(low frequency/high frequency activity ratio, $\mathrm{LF} / \mathrm{HF}$ )와 음의 상관관계가 있는 것으 로 알려져 있다(Doufesh et al., 2014). 아울러 라벤더 오일 흡입은 ANS의 활성화와 세타파 및 알파파의 활성화를 통하여 뇌의 각성 에 영향을 미치는 것으로 보고되고 있다(Sayorwan et al., 2012). 이상의 결과를 종합하면 아로마 에센셜오일은 $\mathrm{ANS}$ 의 균형에 긍 정적인 영향을 미치고 있으며, 에센셜오일의 종류에 따라서 $\mathrm{EEG}$ 의 활성도가 다르게 나타나는 것으로 파악된다.

아로마 에센셜오일과 관련된 선행연구를 살펴보면 에센셜오일 은 부작용이 없고 모든 이에게 다양한 효능이 있는 것으로 알려져 있지만, 그 효능은 개인의 체질적 특성에 따라서 다를 수도 있는 것 으로 보인다. 에센셜오일을 추출한 식물의 학명과 에센셜오일의 맛, 특성, 효용성, 사상체질과의 적합성을 토대로 분류한 연구도 있 으며(Choi et al., 2011), 추출되는 식물의 부위에 따라서 온성오일 과 냉성오일로 분류한 후 온성오일은 혈액형사상체질에 의한 음체 질(A형, $\mathrm{B}$ 형)에 적합하고, 냉성오일은 양체질( $\mathrm{AB}$ 형, $\mathrm{O}$ 형)에 적합한 것으로 보고한 연구도 있다(Heo \& Yoo, 2016). 아울러 혈액형에 따 라서 신경전달물질의 활동이 다르며, $\mathrm{A}$ 형의 경우 중추신경 자극의 전달이 늦고 자극이 사라지는 것도 늦어 심리적 안정성이 높고, B형 의 경우 중추신경 전달이 빠르고 자극이 사라지는 것도 빨라 심리적 안정성이 낮은 것으로 보고되고 있다(Ryu \& Sohn, 2007). 이상의 결과를 토대로 아로마요법은 적용하는 에센셜오일의 열성특성에 따 라서 효능이 다르며, 개인의 체질과 병증에 따라서 적합한 에센셜오 일이 다를 수가 있다는 것을 알 수 있다.

이와 같이 아로마 에센셜오일이 ANS에 영향을 미치는 것이 밝혀 지고 있고, 추출되는 식물의 부위에 따라서 에센셜오일의 열성특성 과 효능이 다르며, 개인의 체질에 따라서 개인에게 적절한 아로마 에 센셜오일이 다르다는 연구결과가 보고되고 있지만, 아로마 흡입이 ANS에 미치는 영향에 대한 체질별 비교를 진행한 연구는 찾기 어려 운 실정이다. 따라서 체질에 따라서 아로마 에센셜오일 흡입이 HRV 와 $\mathrm{EEG}$ 에 미치는 영향이 동일한지 여부를 비교할 필요가 있다.

본 연구의 목적은 30-40대 여성을 대상으로 아로마 에센셜오일 흡입이 $\mathrm{HRV}$ 와 $\mathrm{EEG}$ 에 미치는 영향이 연구대상자의 혈액형사상체 질에 따라서 다르게 나타나는지를 확인하기 위한 것이다. 이를 위 해서 아로마 전문가가 블렌딩한 에센셜오일 흡입에 반응하는 $\mathrm{HRV}$ 와 $\mathrm{EEG}$ 의 변화를 측정하여 연구대상자의 혈액형사상체질에 따라 서 그 변화가 다르게 나타나는지를 비교 분석하였다.

\section{Methods}

\section{1. 연구 대상}

아로마 에센셜오일 흡입 시 에센셜오일의 열성특성에 따라서 $\mathrm{HRV}$ 와 EEG가 다르게 나타나는지를 살펴보기 위하여 전국 피부미 용 서비스업 종사자와 고객을 대상으로 후각기능에 이상이 없고 약 물치료를 받고 있지 않으며 정신질환이나 인지장애가 없는 30-40 대 여성을 모집하여 총 32 명을 선정하였다. 선정된 여성의 혈액형 은 $\mathrm{A}$ 형과 $\mathrm{O}$ 형의 경우 8 명, $\mathrm{AB}$ 형 9 명, $\mathrm{B}$ 형 7 명으로 나타났다. 선정 된 연구대상자들에게 연구에 대한 목적, 내용, 위험 요소 및 사생활 보호 등에 대한 설명을 제공한 후, 자율적 의지에 의한 연구 참여 동의서를 받았다.

자발적 동의로 연구에 참여한 32명의 30-40대 여성을 대상으로 아로마 전문가가 블렌딩한 에센셜오일을 연구대상자의 뒷목 피부 를 통한 흡수와 코를 통한 흡입이 이루어지도록 하였으며, HRV 및 $\mathrm{EEG}$ 는 흡입 전과 흡입 후 $28 \mathrm{~min}$ 동안 매 $4 \mathrm{~min}$ 간격으로 측정된 자료를 사용하였다. 실험은 2016년 8월 1 일부터 8월 31 일까지 한 달 간 진행되었으며, 측정시간은 오후 3 시부터 오후 6 시까지 $3 \mathrm{~h}$ 동안 진행되었다.

\section{2. 연구 도구}

\section{1) 아로마 에센셜오일}

혈액형사상체질별 아로마 에센셜오일이 HRV와 EEG에 미치는 영향을 비교하기 위한 측정을 위하여 연구대상자에게 부과된 아 로마 에센셜오일은 Créations \& Parfums (France)에서 수입하여 Swadsecret (Korea)에서 블렌딩한 오일로 잎사귀에서 추출한 페퍼 민트, 로즈마리, 유칼립투스, 파인, 그리고 열매껍질에서 추출한 레 몬의 5 종 에센셜오일을 $12: 4: 2: 1: 1$ 비율로 혼합하여 구성하였다.

\section{2) $H R V$ 와 $E E G$ 측정}

아로마 에센션오일이 연구대상자의 ANS에 미치는 변화를 파악 하기 위하여 $\mathrm{HRV}$ 와 $\mathrm{EEG}$ 를 동시에 측정하였다. 측정은 외부 소음 과 빛이 차단되고, 온도 $\left(24 \pm 1^{\circ} \mathrm{C}\right)$ 와 습도 $\left(50 \pm 1^{\circ} \mathrm{C}\right)$ 조절이 가능한 뇌파측정실에서 실시하였다.

$\mathrm{HRV}$ 측정은 편안한 안락의자에 앉아 양 팔목, 양 발목에 전 극을 부착하는 표준사지유도 3 채널 유선 심전도 측정시스템인 QECG-3 (LXC3203; Laxtha, Korea)을 사용하여 측정하였다. 저 주파 영역 $(\mathrm{LF})$ 은 $0.04-0.15 \mathrm{~Hz}$ 대역의 심장 동방결절에 대한 교 감신경 조절의 지표이며, $0.15-0.40 \mathrm{~Hz}$ 의 고주파 영역(HF)은 미 주신경 조절의 지표로 이용된다(Task Force of the European Society of Cardiology the North American Society of Pacing Electrophysiology, 1996). 이 연구에서 사용된 HRV 지표는 평균 심 박수(HR), 각 주파수 영역의 절대파워에 자연로그(natural log)를 취한 값으로 교감신경 활성지표인 $\mathrm{LF}$, 부교감신경 활성지표인 $\mathrm{HF}$, 
저주파수 영역과 고주파수 영역 절대파워의 비로 교감신경과 부교 감신경계의 균형을 반영하는 $\mathrm{LF} / \mathrm{HF}$, 그리고 standard deviation of the normal-to normal (NN) intervals (SDNN)을 설정하였다.

$\mathrm{EEG}$ 측정은 전산화 뇌파측정기인 8채널 QEEG-8 (LXE5208; Laxtha)을 사용하였으며, 전극은 국제전극배치법(international 10/20 electrode system)에 의거하여 전전두엽( $\mathrm{Fp} 1, \mathrm{Fp} 2)$, 전두엽 (F3, F4), 측두엽(T3, T4), 두정엽(P3, P4) 총 8부위에 부착하였다. 참조전극은 우측 귓불 뒤, 접지전극은 이마에 부착하였으며, 사용 할 전극은 접시 형태의 디스크 전극으로 뇌파전용 전극 풀(ElefixZ401CE; Nihon Kohden, Japan)을 묻혀 두피에 부착하였다.

연구대상자의 EEG 신호는 샘플링 주파수 $256 \mathrm{~Hz}, 0.6-46 \mathrm{~Hz}$ $(-3 \mathrm{~dB})$ 의 밴드패스 필터(bandpass filter)와 12-bit analog to digital (AD) 변환을 거쳐 컴퓨터에 저장하였다. 수집된 자료를 실 시간 데이터수집 및 시계열분석 프로그램인 TeleScan (ver. 2.99; Laxtha)으로 분석하여 주요 EEG 대역별 상대파워 값을 구하였다. 인공적인 잡파에 의해서 진폭 크기의 총합이 인위적으로 증가되 지 않는 한 상대파워 분석은 절대파워 분석에 비하여 더 정확한 것 으로 알려져 있다(Demos, 2005). 본 연구에서는 전체 주파수 대역 (2-50 Hz)에서 해당 주파수 대역이 차지하는 파워의 비중을 나타내 는 상대파워(relative power) 분석을 실시하였으며, EEG의 주파수 대역을 델타파(delta, $\delta ; 2-4 \mathrm{~Hz}$ ), 세타파(theta, $\theta ; 4-8 \mathrm{~Hz}$ ), 알파파 (alpha, $\alpha$; 8-12 Hz), 감각운동리듬(sensorimotor rhythm, SMR; 12-15 Hz), 베타파(beta, $\beta ; 15-30 \mathrm{~Hz}$ ), 하이베타파(high beta, $\mathrm{H}$ $\beta ; 20-30 \mathrm{~Hz})$, 감마파(gamma, $\gamma ; 30-50 \mathrm{~Hz})$ 로 설정하였고, 아로 마 에센셜오일이 뒷목 부위 피부와 코로 흡수되는 동안의 HRV와 $\mathrm{EEG}$ 의 변화 양상이 연구대상자의 혈액형사상체질에 따라서 다르 게 나타나는지를 비교 분석하기 위한 $\mathrm{EEG}$ 지표는 상대 알파파 (relative alpha), 상대 감각운동리듬(relative SMR), spectral edge frequency (SEF) $-50 \%, \alpha / \mathrm{H} \beta, \theta / \mathrm{SMR}$ 을 설정하여 오일 흡입 전 후 8 개 측정시점에 대한 8 채널 전극부위의 전체 평균값을 산출하 였다.

\section{3. 실험 절차}

이 연구의 목적은 아로마 에센셜오일의 흡입이 연구대상자의 ANS에 미치는 영향이 혈액형사상체질별로 다르게 나타나는지 를 살펴보는 것이다. ANS에 미치는 영향을 살펴보기 위한 $\mathrm{HRV}$ 와 $\mathrm{EEG}$ 측정은 아로마 흡입 후 $20 \mathrm{~min}$ 이면 최대 혈중농도에 이른 다는 연구결과(Jäger et al., 1992)를 토대로 에센셜오일 흡입 전 4 $\min$, 흡입 후 $28 \mathrm{~min}$ 동안 실시하였다.

연구대상자에게는 개인당 페퍼민트 외 4 종의 에센셜을 블렌딩한 에센셜오일을 거즈에 묻혀 뒷목 경추 7 번의 위치에 부착한 상태에 서 $\mathrm{HRV}$ 와 $\mathrm{EEG}$ 를 측정하였다. 연구대상자 1 인당 측정 소요시간은
준비시간을 포함하여 $45 \mathrm{~min}$ 소요되었다. 1명의 측정이 끝나면 향 이 남지 않도록 $30 \mathrm{~min}$ 동안 환기시킨 후 실험을 진행하였다. 1 일 측정인원은 2 명으로 편성하였으며, 한 명이 $\mathrm{HRV}$ 와 $\mathrm{EEG}$ 를 측정하 고 있는 동안에 다른 피험자는 설문지 작성 및 휴식을 취하면서 교 대로 측정하였다. 2 명을 측정하는데 소요되는 총 시간은 실험 설명 을 포함하여 $3 \mathrm{~h}$ 정도가 소요되었다.

구체적 절차는 편안한 안락의자에 앉아 눈을 감고 아무런 자극이 없는 안정상태에서 기준 $\mathrm{HRV}$ 와 $\mathrm{EEG}$ 측정을 $5 \mathrm{~min}$ 간 실시한 후, 준비된 거치대에 지름 $9 \mathrm{~cm}$ 의 도자기 접시를 고정 시킨 후 그 위에 $3.5 \times 3.5 \mathrm{~cm}$ 크기의 거즈를 올려놓은 다음, 페퍼민트 외 4 종의 에 센셜을 블렌딩한 오일 $0.3 \mathrm{~mL}$ 떨어뜨린 거즈를 대상자 뒷목 경추 7 번 부위에 부착하였다.

연구대상자에게는 실험 참여 일주일 전에 참여 날짜, 시간, 주의 사항에 대하여 문자로 전달하고, 하루 전날에는 직접 전화로 주의 사항을 전달하였다. 주의사항으로 측정 전날에는 반드시 충분한 숙 면을 취할 것과 음주 및 심한 신체활동을 금할 것을 요청하였고, 측 정 당일에는 음주나 카페인 섭취를 금하고, 측정 $3 \mathrm{~h}$ 전에는 신경계 에 영향을 줄 수 있는 알코올이나 카페인이 포함된 음식을 복용하 지 않도록 당부하였다.

실험은 측정을 주관하는 전문연구자 1 명과 연구보조원 2 명에 의 해 진행되었다. 연구보조원에게는 실험 절차 및 방법에 대한 교육 을 실시하였으며, 뇌파 전극 부착 및 측정 방법에 익숙하도록 충분 한 사전연습을 실시하였다.

$\mathrm{HRV}$ 와 $\mathrm{EEG}$ 측정에 대한 분석 구간은 에센셜오일 흡입 전 눈 을 감은 편안한 안정상태에서 기준 $\mathrm{HRV}$ 및 $\mathrm{EEG}$ 를 $5 \mathrm{~min}$ 측정하 였고, 그 중 $4 \mathrm{~min}$ (1-5 min)을 흡입 전(Time=1)으로 설정하였다. 오일 흡입 후에는 흡입 후 $28 \mathrm{~min}$ 간 $\mathrm{HRV}$ 와 $\mathrm{EEG}$ 를 측정하였으 며, 매 $4 \mathrm{~min}$ 간격으로 측정시점을 구분하여 흡입 직후(0-4 min; Time=2), 흡입 후 $4 \mathrm{~min}$ (4-8 $\mathrm{min}$; Time=3), 흡입 후 $8 \mathrm{~min}$ (8-12 $\min$; Time=4), 흡입 후 $12 \min (12-16 \min$; Time=5), 흡입 후 16 $\min$ (16-20 min; Time=6), 흡입 후 $20 \mathrm{~min}$ (20-24 min; Time=7), 흡입 후 $24 \mathrm{~min}$ (24-28 min; Time=8)으로 설정하였다. 측정은 오 후 3 시부터 오후 6 시까지 $3 \mathrm{~h}$ 동안 진행되었다.

\section{4. 자료 분석}

연구대상자가 페퍼민트 외 4종의 에센셜을 블렌딩한 오일 흡 입 후 시간의 경과에 따른 $\mathrm{HRV}$ 와 $\mathrm{EEG}$ 변화 양상이 연구대상자의 혈액형사상체질에 따라서 차이가 있는지를 살펴보기 위하여 반 복측정 분산분석[analysis of variance (ANOVA) with repeated measures]을 실시하였으며, 통계분석을 위하여 Statistical Package for the Social Sciences (SPSS ver. 24.0; IBM, USA)과 R (ver. 3.3.3; R foundation, Austria)을 사용하였다. 


\section{Results and Discussion}

\section{1. 심박변이도(HRV)}

1) 평균 심박수(HR)

페퍼민트 외 4종의 에센셜을 블렌딩한 오일 흡입 전후 측정시점 에 따라 분당 평균 $\mathrm{HR}$ 에 미치는 영향이 피실험자의 혈액형에 따라 서 다르게 나타나는지를 살펴보기 위한 반복측정 분산분석 결과는 Table 1과 같게 나타났으며, 각 측정시점과 연구대상자의 혈액형별 평균 $\mathrm{HR}$ 값의 관계를 나타내는 그림은 Figure 1과 같다.

Table 1을 살펴보면, 혈액형(BT) ( $p=0.028)$, 측정시점(Time) $(p<0.001)$, 혈액형과 측정시점의 상호작용 $(\mathrm{BT} \times \mathrm{Time})(p=0.010)$ 모 두 통계적으로 유의하게 나타났다. 이는 각 측정시점에서 측정한 평균 $\mathrm{HR}$ 값의 평균은 연구대상자의 혈액형에 따라서 동일하지 않 으며, 측정시점에 따라서 동일하지 않고, 측정시점에 따른 평균의 변화가 혈액형별로 다르다는 것을 의미하는 것이다.

사후분석을 통하여 각 측정시점별로 혈액형별 평균 비교를 한 결 과, 흡입 후 $20 \mathrm{~min}(\mathrm{Time}=7)$ 과 $24 \mathrm{~min}(\mathrm{Time}=8)$ 측정시점에 $\mathrm{O}$ 형 의 평균 $\mathrm{HR}$ (Time=7, $77.298 \mathrm{bpm}$; Time=8, $76.698 \mathrm{bpm}$ )은 A형 의 평균 $\mathrm{HR}$ (Time=7, $61.997 \mathrm{bpm}$; Time=8, $62.158 \mathrm{bpm}$ )보다 높 게 나타났다 $(p<0.05)$ (Figure 1). 따라서 페퍼민트 외 4종의 에센셜 을 블렌딩한 오일 흡입 전후 측정시점에 따른 평균 $\mathrm{HR}$ 의 변화가 연
구대상자의 혈액형에 따라서 다르게 나타난다는 것을 확인하였다.

2) 교감신경 활성도(LF) 및 부교감신경 활성도(HF)

블렌딩 오일 흡입이 오일 흡입 전후 측정시점에 따라서 $\mathrm{LF}$ 와 $\mathrm{HF}$ 에 미치는 영향이 피실험자의 혈액형에 따라서 다르게 나타나는지를 살펴보기 위한 반복측정 분산분석 결과는 Table 1과 같게 나타났다.

Table 1을 살펴보면, $\mathrm{LF}$ 의 경우 측정시점에 따른 변화는 유의미 하게 나타났지만 $(p<0.001)$, 그 변화의 양상이 혈액형에 따라서 동일 한 것으로 나타났다 $(p=0.154) . \mathrm{HF}$ 의 경우도 마찬가지로 측정시점 에 따른 변화는 유의미하게 나타났지만 $(p<0.001)$, 그 변화의 양상 이 혈액형에 따라서 동일한 것으로 나타났다 $(p=0.897)$. 이는 연구 대상자의 혈액형별로 각 측정시점에서 측정한 $\mathrm{LF}$ 와 $\mathrm{HF}$ 값의 평균 은 측정시점에 따라서 동일하지 않지만, 측정시점에 따른 평균의 변화가 혈액형별로 동일하다는 것을 의미하는 것이다. 따라서 본 연구에서는 $\mathrm{LF}$ 와 $\mathrm{HF}$ 의 경우 페퍼민트 외 4 종의 에센셜을 블렌딩 한 오일 흡입 전후 측정시점에 따른 변화가 연구대상자의 혈액형에 따라서 다르게 나타나지 않았다.

3) 교감신경 활성도와 부교감신경 활성도의 비(LF/HF)

페퍼민트 외 4종의 에센셜을 블렌딩한 오일 흡입이 오일 흡입 전 후 측정시점에 따라서 $\mathrm{LF} / \mathrm{HF}$ 에 미치는 영향이 피실험자의 혈액형

Table 1. Analysis of the effects of BT and duration of essential oil inhalation on HRV indices using repeated measures ANOVA

\begin{tabular}{|c|c|c|c|c|c|c|c|}
\hline Measures & Source & & SS & $\mathrm{df}$ & MS & $F$ & $p$ \\
\hline \multirow{3}{*}{ Average HR } & Between & BT & 5534.326 & 3 & 1844.775 & 3.522 & $0.028^{*}$ \\
\hline & \multirow{2}{*}{ Within } & Time & 395.752 & 7 & 56.536 & 12.261 & $<0.001^{* * *}$ \\
\hline & & BT×Time & 188.220 & 21 & 8.963 & 1.944 & $0.010^{*}$ \\
\hline \multirow{3}{*}{ LF } & Between & BT & 12.138 & 3 & 4.046 & 0.960 & 0.425 \\
\hline & \multirow{2}{*}{ Within } & Time & 22.586 & 7 & 3.227 & 9.834 & $<0.001^{* * *}$ \\
\hline & & BT $\times$ Time & 9.234 & 21 & 0.440 & 1.340 & 0.154 \\
\hline \multirow{3}{*}{$\mathrm{HF}$} & Between & BT & 38.476 & 3 & 12.825 & 1.695 & 0.191 \\
\hline & \multirow{2}{*}{ Within } & Time & 4.656 & 7 & 0.665 & 6.059 & $<0.001^{* * *}$ \\
\hline & & BT $\times$ Time & 1.442 & 21 & 0.069 & 0.625 & 0.897 \\
\hline \multirow{3}{*}{ LF/HF } & Between & BT & 106.394 & 3 & 35.465 & 3.972 & $0.018^{*}$ \\
\hline & \multirow{2}{*}{ Within } & Time & 32.052 & 7 & 4.579 & 5.494 & $<0.001^{* * *}$ \\
\hline & & BT $\times$ Time & 31.058 & 21 & 1.479 & 1.775 & $0.023^{*}$ \\
\hline \multirow{3}{*}{ SDNN } & Between & BT & 783.119 & 3 & 261.040 & 0.238 & 0.869 \\
\hline & \multirow{2}{*}{ Within } & Time & 1876.657 & 7 & 268.094 & 4.425 & $<0.001^{* * *}$ \\
\hline & & BT×Time & 1251.229 & 21 & 59.582 & 0.984 & 0.485 \\
\hline
\end{tabular}

BT, blood type; HRV, heart rate variability; ANOVA, analysis of variance; HR, heart rate; LF, low frequency; HF, high frequency; SDNN, standard deviation of the normal-to-normal intervals; SS, sum of squares; df, degrees of freedom; MS, mean squares; " $p<0.05$; ${ }^{* * *} p<0.001$; Error terms are not shown. 


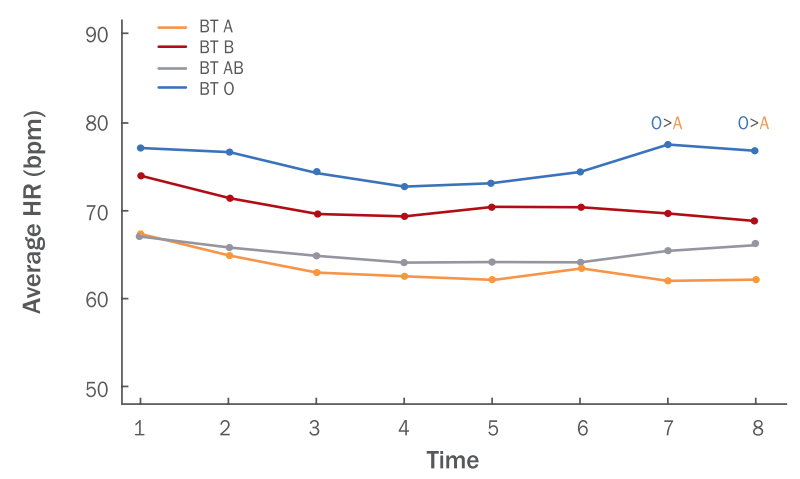

Figure 1. Average HR at each time point for the different BTs.

Means were calculated using repeated measures ANOVA. Each point represents the average $\mathrm{HR}$ at the measured time points for BT A, B, AB, and O. O>A indicates that the average HR of BT O is greater than that of BT A at time points 7 and $8(p<0.05)$. HR, heart rate; BT, blood type; ANOVA, analysis of variance.

에 따라서 다르게 나타나는지를 살펴보기 위한 반복측정 분산분석 결과는 Table 1과 같게 나타났으며, 각 측정시점과 연구대상자의 혈 액형별 평균 $\mathrm{LF} / \mathrm{HF}$ 값의 관계를 나타내는 그림은 Figure 2 와 같다.

Table 1을 살펴보면, BT ( $p=0.018)$, Time ( $p<0.001)$, BT $\times$ Time $(p=0.023)$ 모두 통계적으로 유의하게 나타났다. 이는 각 측정시점

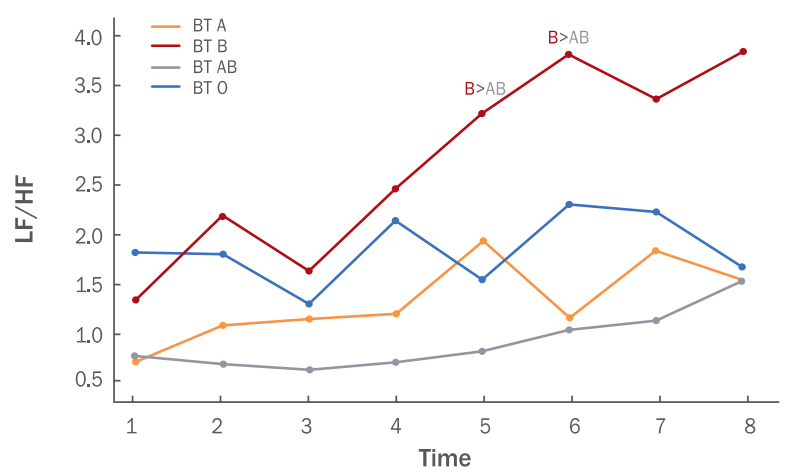

Figure 2. LF/HF ratio at each time point for the different BTs. Means were calculated using repeated measures ANOVA. Each point represents the LF/HF ratio at the measured time points for $B T A, B, A B$, and $O . B>A B$ indicates that the $L F / H F$ ratio of $B T B$ is greater than that of $B T A B$ at time points 5 and $6(p<0.05)$. LF, low frequency; HF, high frequency; BT, blood type; ANOVA, analysis of variance

에서 측정한 $\mathrm{LF} / \mathrm{HF}$ 값의 평균은 연구대상자의 혈액형에 따라서 동 일하지 않으며, 측정시점에 따라서 동일하지 않고, 측정시점에 따 른 평균의 변화가 혈액형별로 다르다는 것을 의미하는 것이다.

사후분석을 통하여 각 측정시점별로 혈액형별 평균 비교를 한

Table 2. Analysis of the effects of BT and duration of essential oil inhalation on EEG parameters using repeated measures ANOVA

\begin{tabular}{|c|c|c|c|c|c|c|c|}
\hline Measures & Source & & SS & $\mathrm{df}$ & MS & $F$ & $p$ \\
\hline \multirow{3}{*}{ Relative alpha } & Between & BT & 0.415 & 3 & 0.138 & 1.096 & 0.367 \\
\hline & \multirow{2}{*}{ Within } & Time & 1.142 & 7 & 0.163 & 19.158 & $<0.001^{* * *}$ \\
\hline & & BT×Time & 0.383 & 21 & 0.018 & 2.140 & $0.004^{* *}$ \\
\hline \multirow{3}{*}{ Relative SMR } & Between & BT & 0.033 & 3 & 0.011 & 2.582 & 0.073 \\
\hline & \multirow{2}{*}{ Within } & Time & 0.002 & 7 & 0.000 & 0.575 & 0.776 \\
\hline & & BT×Time & 0.012 & 21 & 0.001 & 1.205 & 0.250 \\
\hline \multirow{3}{*}{ SEF-50\% } & Between & BT & 9.783 & 3 & 3.261 & 0.094 & 0.963 \\
\hline & \multirow{2}{*}{ Within } & Time & 289.051 & 7 & 41.293 & 8.891 & $<0.001^{* * *}$ \\
\hline & & BT $\times$ Time & 92.016 & 21 & 4.382 & 0.943 & 0.536 \\
\hline \multirow{3}{*}{$\alpha / H \beta$} & Between & BT & 600.149 & 3 & 200.050 & 2.326 & $0.096^{+}$ \\
\hline & \multirow{2}{*}{ Within } & Time & 530.354 & 7 & 75.765 & 13.508 & $<0.001^{* * *}$ \\
\hline & & BT×Time & 183.547 & 21 & 8.740 & 1.558 & $0.063^{+}$ \\
\hline \multirow{3}{*}{$\theta / \mathrm{SMR}$} & Between & BT & 67.981 & 3 & 22.660 & 0.920 & 0.444 \\
\hline & \multirow{2}{*}{ Within } & Time & 36.805 & 7 & 5.258 & 3.083 & $0.004^{* *}$ \\
\hline & & BT $\times$ Time & 17.876 & 21 & 0.851 & 0.499 & 0.968 \\
\hline
\end{tabular}

BT, blood type; EEG, electroencephalogram; ANOVA, analysis of variance; SMR, sensorimotor rhythm; SEF, spectral edge frequency; $\alpha$, alpha; $\mathrm{H} \beta$, high beta; $\theta$, theta; SS, sum of squares; df, degrees of freedom; MS, mean squares; ${ }^{+} p<0.1 ;{ }^{* *} p<0.01$; ${ }^{* * *} p<0.001$; Error terms are not shown. 


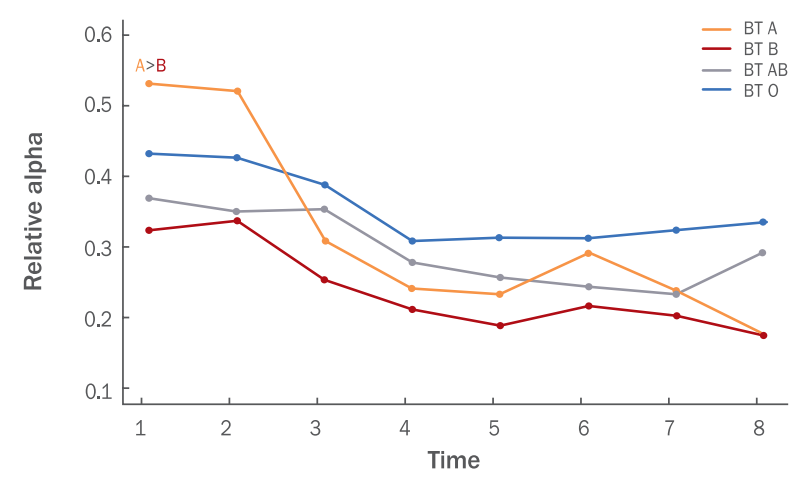

Figure 3. Relative alpha at each time point for the different BTs. Means were calculated using repeated measures ANOVA. Each point represents the relative alpha at the measured time points for $\mathrm{BT} A, \mathrm{~B}, \mathrm{AB}$, and $\mathrm{O}$. A>B indicates that the relative alpha of $\mathrm{BT}$ $A$ is greater than that of BT $B$ at the first time point $(p<0.05)$. BT, blood type; ANOVA, analysis of variance.

결과, 흡입 후 $12 \min (\mathrm{Time}=5)$ 과 $16 \mathrm{~min}(\mathrm{Time}=6)$ 측정시점에 $\mathrm{B}$ 형의 $\mathrm{LF} / \mathrm{HF}$ (Time=5, 3.158; Time=6, 3.773)는 $\mathrm{AB}$ 형의 $\mathrm{LF} /$ $\mathrm{HF}$ (Time=5, 0.847; Time=6, 1.038)보다 높게 나타났다 $(p<0.05)$ (Figure 2). 따라서 페퍼민트 외 4종의 에센셜을 블렌딩한 오일 흡 입 전후 측정시점에 따른 ANS 균형도의 변화가 연구대상자의 혈액 형에 따라서 다르게 나타난다는 것을 확인하였다.

\section{4) NN간격 표준편차(SDNN)}

페퍼민트 외 4종의 에센셜을 블렌딩한 오일 흡입이 오일 흡입 전 후 측정시점에 따라서 $\mathrm{SDNN}$ 에 미치는 영향이 연구대상자의 혈액 형에 따라서 다르게 나타나는지를 살펴보기 위한 반복측정 분산분 석 결과는 Table 1 과 같게 나타났다.

Table 1을 살펴보면, $\mathrm{SDNN}$ 의 경우 측정시점에 따른 변화는 유의 미하게 나타났지만 $(p<0.001)$, 그 변화의 양상이 혈액형에 따라서 동 일한 것으로 나타났다 $(p=0.485)$. 이는 각 측정시점에서 측정한 연 구대상자의 $\mathrm{SDNN}$ 값의 평균은 측정시점에 따라서 동일하지 않지 만, 측정시점에 따른 평균의 변화가 혈액형별로 동일하다는 것을 의미하는 것이다. 따라서 본 연구에서는 일반적으로 스트레스에 대 한 저항력을 나타내는 $\mathrm{SDNN}$ 의 경우 페퍼민트 외 4종의 에센셜을 블렌딩한 오일 흡입 전후 측정시점에 따른 변화가 연구대상자의 혈 액형에 따라서 다르게 나타나지 않았다.

\section{2. 뇌파(EEG)}

1) 상대 알파파(relative alpha)

페퍼민트 외 4종의 에센셜을 블렌딩한 오일 흡입이 오일 흡입 전 후 측정시점에 따라서 상대 알파파에 미치는 영향이 연구대상자의 혈액형에 따라서 다르게 나타나는지를 살펴보기 위한 반복측정 분 산분석 결과는 Table 2 와 같게 나타났으며, 각 측정시점과 연구대

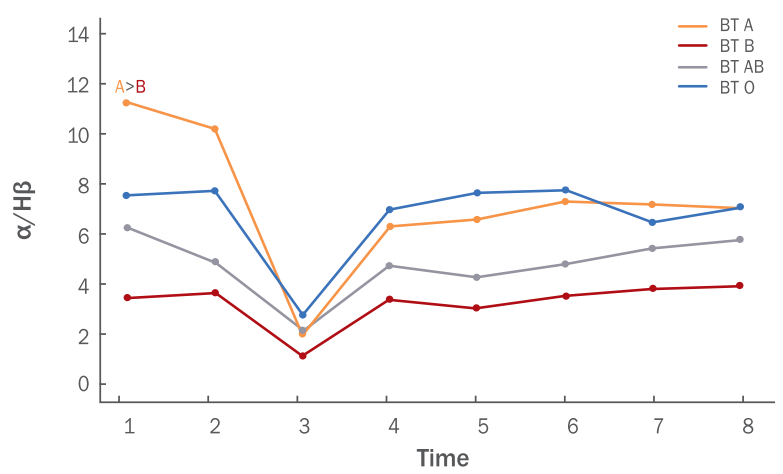

Figure 4. $\alpha / \mathrm{H} \beta$ ratio at each time point for the different BTs. Means were calculated using repeated measures ANOVA. Each point represents the $\alpha / H \beta$ ratio at the measured time points for BT $A, B, A B$, and $O$. $A>B$ indicates that the $\alpha / H \beta$ ratio of $B T A$ is greater than that of $B T B$ at the first time point $(p<0.05) . \alpha$, alpha; $\mathrm{H} \beta$, high beta; BT, blood type; ANOVA, analysis of variance.

상자의 혈액형별 평균 상대 알파파 값의 관계를 나타내는 그림은 Figure 3과 같다.

Table 2 를 살펴보면, Time ( $p<0.001), \mathrm{BT} \times \operatorname{Time}(p=0.004)$ 모두 통계적으로 유의하게 나타났다. 이는 연구대상자의 혈액형별로 각 측정시점에서 측정한 상대 알파파 값의 평균은 측정시점에 따라서 동일하지 않고, 측정시점에 따른 평균의 변화는 혈액형별로 다르다 는 것을 의미하는 것이다.

사후분석을 통하여 각 측정시점에서 혈액형별 평균 비교를 한 결 과 흡입 전(Time=1) 측정시점에 $\mathrm{A}$ 형의 상대 알파파 $(0.534)$ 는 $\mathrm{B}$ 형 의 상대 알파파(0.325)보다 높게 나타났다 $(p<0.05)$ (Figure 3). 따라 서 페퍼민트 외 4종의 에센셜을 블렌딩한 오일 흡입 전후 측정시점 에 따른 상대 알파파의 변화가 연구대상자의 혈액형에 따라서 다르 게 나타난다는 것을 확인하였다.

\section{2) 상대 감각운동리듬(relative SMR)}

페퍼민트 외 4종의 에센셜을 블렌딩한 오일 흡입이 오일 흡입 전 후 측정시점에 따라서 relative SMR에 미치는 영향이 연구대상자의 혈액형에 따라서 다르게 나타나는지를 살펴보기 위한 반복측정 분 산분석 결과는 Table 2 와 같게 나타났다.

Table 2 를 살펴보면, relative SMR의 경우 BT, Time, BT×Time 모두 통계적으로 유의미하게 나타나지 않았다. 따라서 본 연구에서 는 relative SMR의 경우 페퍼민트 외 4종의 에센셜을 블렌딩한 오 일 흡입 전후 측정시점에 따른 변화가 연구대상자의 혈액형에 따라 서 다르게 나타나지 않았다.

3) $50 \%$ 누적 스펙트럼 주파수(SEF-50\%)

페퍼민트 외 4종의 에센셜을 블렌딩한 오일 흡입이 오일 흡입 전 후 측정시점에 따라서 SEF-50\%에 미치는 영향이 피실험자의 혈액 
형에 따라서 다르게 나타나는지를 살펴보기 위한 반복측정 분산분 석 결과는 Table 2 와 같게 나타났다.

Table 2를 살펴보면, SEF-50\%의 경우 Time의 변화에 따른 평 균 값 변화가 유의미하게 나타났지만 $(p<0.001), \mathrm{BT}$ 와 BT×Time 모 두 통계적으로 유의미하게 나타나지 않았다. 따라서 본 연구에서는 $\mathrm{SEF}-50 \%$ 의 경우 페퍼민트 외 4종의 에센셜을 블렌딩한 오일 흡입 전후 측정시점에 따른 변화가 존재하지만, 그 변화의 양상이 연구 대상자의 혈액형에 따라서 다르게 나타나지 않았다.

\section{4) 알파파와 하이베타파의 비( $\alpha / H \beta)$}

페퍼민트 외 4종의 에센셜을 블렌딩한 오일 흡입이 오일 흡입 전 후 측정시점에 따라서 $\alpha / \mathrm{H} \beta$ 에 미치는 영향이 연구대상자의 혈액형 에 따라서 다르게 나타나는지를 살펴보기 위한 반복측정 분산분석 결과는 Table 2 와 같게 나타났으며, 각 측정시점과 연구대상자의 혈 액형별 평균 $\alpha / \mathrm{H} \beta$ 값의 관계를 나타내는 그림은 Figure 4 와 같다.

Table 2 를 살펴보면, $\alpha / \mathrm{H} \beta$ 의 경우 Time의 변화에 따른 평균 값 변 화가 유의미하게 나타났지만 $(p<0.001), \mathrm{BT}(p=0.096)$ 와 BT $\times \mathrm{Time}$ $(p=0.063)$ 모두 유의수준 $5 \%$ 에서 유의미하게 나타나지 않았다. 따 라서 $\alpha / \mathrm{H} \beta$ 의 경우 페퍼민트 외 4종의 에센셜을 블렌딩한 오일 흡입 전후 측정시점에 따른 변화가 존재하지만, 그 변화의 양상이 연구대 상자의 혈액형에 따라서 다르게 나타난다고 판단하기에는 증거가 미약한 것으로 보인다. 하지만 사후분석을 통하여 각 측정시점별로 혈액형별 평균 비교를 한 결과 흡입 전(Time=1) 측정시점에 $\mathrm{A}$ 형의 $\alpha$ $/ \mathrm{H} \beta$ 값(11.260)은 $\mathrm{B}$ 형의 $\alpha / \mathrm{H} \beta$ 값(3.543)보다 높게 나타났다 $(p<0.05)$ (Figure 4), 이는 페퍼민트 외 4종의 에센셜을 블렌딩한 오일 흡입 전 후 측정시점에 따른 $\alpha / \mathrm{H \beta}$ 의 변화가 연구대상자의 혈액형에 따라서 다르게 나타날 수 있다는 것을 시사하는 것으로 사료된다.

\section{5) 세타파와 감각운동리듬의 비 $(\theta / S M R)$}

페퍼민트 외 4종의 에센셜을 블렌딩한 오일 흡입이 오일 흡입 전 후 측정시점에 따라서 $\theta / \mathrm{SMR}$ 에 미치는 영향이 연구대상자의 혈액 형에 따라서 다르게 나타나는지를 살펴보기 위한 반복측정 분산분 석 결과는 Table 2 와 같게 나타났다.

Table 2 를 살펴보면, $\theta / \mathrm{SMR}$ 의 경우 Time의 변화에 따른 평균 값 변화가 유의미하게 나타났지만 $(p=0.004), \mathrm{BT}$ 와 BT $\times$ Time 모 두 통계적으로 유의미하게 나타나지 않았다. 따라서, 본 연구에서 는 $\theta / \mathrm{SMR}$ 의 경우 페퍼민트 외 4종의 에센셜을 블렌딩한 오일 흡입 전후 측정시점에 따른 변화가 존재하지만, 그 변화의 양상이 연구 대상자의 혈액형에 따라서 다르게 나타나지 않았다.

\section{Conclusion}

본 연구의 목적은 페퍼민트 외 4종의 에센셜을 블렌딩한 오일 흡 입 전후 시간의 경과에 따른 HRV와 EEG 변화 양상이 연구대상자 의 혈액형사상체질에 따라서 차이가 있는지를 확인하기 위한 것이 다. 이를 위하여 30-40대 여성을 대상으로 오일 흡입하기 전, 흡입 직후, 흡입 후 $4 \mathrm{~min}, 8 \mathrm{~min}, 12 \mathrm{~min}, 16 \mathrm{~min}, 20 \mathrm{~min}, 24 \mathrm{~min}$ 에 각각 $4 \mathrm{~min}$ 간 측정한 $\mathrm{HRV}$ 와 $\mathrm{EEG}$ 특성을 연구대상자의 혈액형별 로 비교하기 위하여 반복측정 분산분석을 실시하였으며, 분석결과 에센셜오일 흡입이 HRV와 EEG에 미치는 영향이 연구대상자의 혈 액형사상체질에 따라서 다르게 나타나고 있음을 확인하였고, 그 주 요 내용은 다음과 같다.

첫째, 페퍼민트 외 4종의 에센셜을 블렌딩한 오일 흡입이 오일 흡입 경과시간에 따라서 분당 평균 $\mathrm{HR}$ 에 미치는 영향이 연구대상 자의 혈액형에 따라서 다르게 나타나는지를 살펴본 결과, 혈액형 $\mathrm{O}$ 형 집단과 $\mathrm{A}$ 형 집단은 에센셜오일을 흡입하기 전부터, 흡입 후 16 $\mathrm{min}$ 경과 시까지 평균 $\mathrm{HR}$ 의 차이가 나타나지 않았지만, 흡입 후 $20 \mathrm{~min}$ 이후부터는 혈액형 $\mathrm{O}$ 형 집단이 $\mathrm{A}$ 형 집단보다 평균 $\mathrm{HR}$ 가 높게 나타났다. 이는 본 연구의 실험에 사용된 페퍼민트 외 4종의 에센셜을 블렌딩한 오일은 추출되는 식물의 부위에 따른 에센셜오 일 분류방법에 의하면 냉성오일로 분류되며(Heo \& Yoo, 2016), 냉 성오일의 경우 에센셜오일 흡입 후 $20 \mathrm{~min}$ 경과 시부터 혈액형사상 체질에 의해서 양성체질로 분류되는 $\mathrm{O}$ 형(소양인)의 평균 $\mathrm{HR}$ 을 음 성체질로 분류되는 $\mathrm{A}$ 형(태음인)에 비하여 활성화시키는 효과가 있 다는 것을 의미한다. 이 결과는 $\mathrm{A}$ 형이 $\mathrm{O}$ 형보다 심리적 안정성이 높 다는 Ryu \& Sohn (2007)의 연구결과와 결부하여 볼 때 냉성오일은 심리적으로 안정적인 $\mathrm{A}$ 형의 경우보다 심리적으로 불안정한 성향을 나타내는 $\mathrm{O}$ 형의 경우에 오일 흡입 후 $20 \mathrm{~min}$ 경과시점부터 평균 $\mathrm{HR}$ 을 활성화시키는 효과가 있는 것으로 사료된다.

둘째, 페퍼민트 외 4종의 에센셜을 블렌딩한 오일 흡입이 오일 흡입 경과시간에 따라서 $\mathrm{LF} / \mathrm{HF}$ 에 미치는 영향이 연구대상자의 혈 액형에 따라서 다르게 나타나는지를 살펴본 결과, 오일 흡입 후 12 $\min$ 부터 흡입 후 $20 \mathrm{~min}$ 까지는 혈액형 $\mathrm{B}$ 형 집단이 혈액형 $\mathrm{AB}$ 형 집단의 $\mathrm{LF} / \mathrm{HF}$ 값보다 더 크게 나타났다. 이는 혈액형사상체질에 의해서 냉성체질인 $\mathrm{B}$ 형(소음인)이 열성체질인 $\mathrm{AB}$ 형(태양인)에 비 해서 페퍼민트 외 4 종의 에센셜을 블렌딩한 오일 흡입 후 $12 \mathrm{~min}$ 경 과 시부터 $20 \mathrm{~min}$ 까지 교감신경이 활성화되는 효과를 가진다는 것 을 의미한다. 심리적으로 불안전성이 가장 높은 B형(Ryu \& Sohn, 2007)의 경우, 정상인의 ANS 균형도 평균은 1.5 정도이고, 범위는 
0.2-2.0 사이를 나타낸다는 연구결과(Kim et al., 2009; Malik et al., 1996)와 결부하여 볼 때, 냉성오일은 심리적으로 불안정성이 가 장 높은 B형의 LF를 증가시키는 효과가 있는 것으로 사료된다.

셋째, 페퍼민트 외 4종의 에센셜을 블렌딩한 오일 흡입이 오일 흡입 경과시간에 따라서 상대 알파파에 미치는 영향이 연구대상자 의 혈액형에 따라서 다르게 나타나는지를 살펴본 결과, 오일을 흡 입하기 전에는 혈액형 $\mathrm{A}$ 형 집단이 $\mathrm{B}$ 형 집단보다 상대 알파파가 높 게 나타났지만, 오일 흡입 직후부터는 상대 알파파의 차이가 나타 나지 않았다. 오일 흡입 전에 나타난 A형과 B형의 상대 알파파 차 이는 알파파 활성도는 심리적 안정상태를 유발하고(Diego et al., 1998; Jung \& Lim, 2016), A형이 심리적 안정성이 가장 높고, B형 의 심리적 안정성이 가장 낮다는 연구결과(Ryu \& Sohn, 2007)를 참고하면 $\mathrm{A}$ 형과 $\mathrm{B}$ 형의 기질적인 차이에 의해서 발생한 것으로 사 료된다. 이러한 $\mathrm{A}$ 형과 $\mathrm{B}$ 형의 기질적인 차이로 인하여 발생한 오일 흡입 전의 상대 알파파 차이는 냉성오일 흡입으로 인하여 없어진 것으로 사료된다.

넷째, 페퍼민트 외 4종의 에센셜을 블렌딩한 오일 흡입이 오일 흡입 경과시간에 따라서 $\alpha / \mathrm{H} \beta$ 값에 미치는 영향이 연구대상자의 혈 액형에 따라서 다르게 나타나는지를 살펴본 결과, 오일을 흡입하기 전에는 혈액형 $\mathrm{A}$ 형 집단이 $\mathrm{B}$ 형 집단보다 $\alpha / \mathrm{H} \beta$ 값이 높게 나타났지 만, 오일 흡입 직후부터는 $\alpha / \mathrm{H} \beta$ 값의 차이가 나타나지 않았다. 오 일 흡입 전의 차이는 오일 흡입 전에 심리적 안정성이 높은 A형(태 음인)과 심리적 안정성이 낮은 B형(소음인)의 기질적인 차이로 인하 여 발생한 것으로 보이며(Ryu \& Sohn, 2007), 이러한 오일 흡입 전 의 $\alpha / \mathrm{H} \beta$ 값의 차이는 냉성오일 흡입으로 인하여 없어진 것으로 사 료된다. 아울러 오일흡입 후 $4 \mathrm{~min}$ (Time=3)에 모든 혈액형에서 $\alpha$ $/ \mathrm{H} \beta$ 값이 감소한 현상은 로만 카모마일 흡입이 알파파의 증가와 베 타파의 감소를 유발한다는 Jung \& Lim (2016)의 연구와는 다른 결 과이지만 로만 카모마일 에센셜오일은 식물의 꽃에서 추출한 오일 로 온성오일로 분류되는 것을 감안할 때(Heo \& Yoo, 2016), 본 연구 에서 사용된 냉성오일은 알파파의 감소와 베타파의 증가를 유발하 고 있는 것이 확인된 것으로 선행연구의 결과들과 일치되는 것으로 사료된다.

이상의 결과를 요약하면 냉성오일로 분류될 수 있는 페퍼민트 외 4 종의 에센셜을 블렌딩한 오일 흡입 전후 시간의 경과에 따른 평균 $\mathrm{HR}, \mathrm{LF} / \mathrm{HF}$, 상대 알파파 변화가 혈액형사상체질에 따라서 다르게 나타나고 있음을 확인하였다.

본 연구에서는 각 혈액형별로 7-9명을 측정하였으므로 좀 더 구 체적인 차이를 발견하기 위해서는 연구대상자의 수를 늘려서 분석 할 필요가 있다고 본다. 아울러 본 연구에서는 냉성오일로 분류할 수 있는 에센셜오일 흡입이 HRV와 EEG에 미치는 영향을 살펴보 기 위한 연구설계를 설정하였지만 보다 심도 깊은 연구를 위하여 통제집단과 냉성오일 흡입 집단을 설정한 설계의 연구도 필요하다 고 보며 이는 추후의 연구과제로 남겨둔다.

\section{References}

Buckle J. Use of aromatherapy as a complementary treatment for chronic pain. Alternative Therapies in Health and Medicine, 5: 42-51, 1999.

Buckley J. Massage and aromatherapy massage: nursing art and science. International Journal of Palliative Nursing, 8: 276-280, 2002.

Choi EJ, Hong SG, Yoo JS. Classification of aroma essential oils by sasang constitution. Journal of Sasang Constitutional Medicine, 23: 304-317, 2011.

Demos JN. Getting started with neurofeedback. W. W. Norton \& Company, New York, pp149-152, 2005.

Diego MA, Jones NA, Field T, Hernandez-Reif M, Schanberg S, Kuhn C, McAdam V, Galamaga R, Galamaga M. Aromatherapy positively affects mood, EEG patterns of alertness and math computations. International Journal of Neuroscience, 96: 217-224, 1998.

Doufesh H, Ibrahim F, Ismail NA, Wan Ahmad WA. Effect of muslim prayer (salat) on $\alpha$ electroencephalography and its relationship with autonomic nervous system activity. Journal of Alternative and Complementary Medicine, 20: 558-562, 2014.

Dunn C, Sleep J, Collett D. Sensing an improvement: an experimental study to evaluate the use of aromatherapy, massage and periods of rest in an intensive care unit. Journal of Advanced Nursing, 21: 34-40, 1995.

Heo SH, Yoo S. Relations between aroma essential oil blending based on oil characteristics and In-San body constitution based on blood type. Journal of the Korean Society of Cosmetology, 22: 1236-1244, 2016.

lijima M, Osawa M, Nishitani N, Iwata M. Effects of incense on brain function: evaluation using electroencephalograms and event-related potentials. Neuropsychobiology, 59: 80-86, 2009.

Jäger W, Buchbauer G, Jirovetz L, Fritzer M. Percutaneous absorption of lavender oil from a massage oil. Journal of the Society of Cosmetic Chemists, 43: 49-54, 1992.

Jeon YA, Woo N. A meta-analysis of obesity management effects of aromatherapy use. Asian Journal of Beauty and Cosmetology, 12: 275-281, 2014.

Jung SH, Lim MH. The effect of roman chamomile inhalation on autonomic nervous system in middle aged women. Journal of the Korean Society of Cosmetology, 22: 636- 
643, 2016.

Kim MW, Yoo YS, Cho OH, Jo SJ. The effects of aroma inhalation therapy on anxiety and heart rate variability in the patients undergoing urodynamic study. Journal of Korean Biological Nursing Science, 11: 32-41, 2009.

Malik M, Camm AJ, Bigger JT, Breithardt G, Cerutti S, Cohen RJ, Coumel P, Fallen EL, Kennedy HL, Kleiger RE, et al. Heart rate variability: standards of measurement, physiological interpretation, and clinical use. European Heart Journal, 17: 354-381, 1996.

Masago R, Matsuda T, Kikuchi Y, Miyazaki Y, Iwanaga K, Harada $\mathrm{H}$, Katsuura T. Effects of inhalation of essential oils on EEG activity and sensory evaluation. Journal of Physiological Anthropology and Applied Human Science, 19: 35-42, 2000.

Ryu S, Sohn YW. A review of sociocultural, behavioral, biochemical analyses on ABO blood-groups typology.
Korean Journal of Social and Personality Psychology, 21: 27-55, 2007.

Sayorwan W, Siripornpanich V, Piriyapunyaporn T, Hongratanaworakit T, Kotchabhakdi N, Ruangrungsi $\mathrm{N}$. The effects of lavender oil inhalation on emotional states, autonomic nervous system, and brain electrical activity. Journal of the Medical Association of Thailand, 95: 598-606, 2012.

Shin YS, Cho YS, Jung YJ. The effects of aromatherapy on autonomic nerve system and physical resistance of a stress. Journal of Korean Biological Nursing Science, 6: 5-17, 2004.

Task Force of the European Society of Cardiology the North American Society of Pacing Electrophysiology. Heart rate variability: standards of measurement, physiological interpretation, and clinical use. Circulation, 93: 10431065, 1996. 


\section{국문초록}

\section{에센셜오일 흡입이 자율신경계에 미치는 영향에 대한 혈액형사상체질 집단 비교}

허선희 ${ }^{1}$, 심준영 ${ }^{2}$ 유성모 ${ }^{2 *}$

${ }^{1}$ 뉴로아로마콜로지 연구소, 인천, 한국

${ }^{2}$ 국제뇌교육종합대학원대학교 뇌교육학과, 충청남도 천안시, 한국

목적: 본 연구의 목적은 에센셜오일 흡입이 자율신경계에 미치는 영향을 혈액형사상체질 집단에 따라 비교하는 것이다. 방법: 페 퍼민트, 로즈마리, 유칼립투스, 파인, 레몬을 $12: 4: 2: 1: 1$ 비율로 혼합한 블렌딩 오일을 구성하여, 중년 여성 32 명을 대상으로 블렌 딩한 아로마 오일을 거즈에 적신 후 연구대상자의 뒷목에 $28 \mathrm{~min}$ 동안 부착하였다. 심박변이도와 뇌파는 $4 \mathrm{~min}$ 간격으로 흡입 전, 흡입 직후, 흡입 후 $4 \mathrm{~min}, 8 \mathrm{~min}, 12 \mathrm{~min}, 16 \mathrm{~min}, 20 \mathrm{~min}, 24 \mathrm{~min}$ 에 측정하였다. 결과: 블렌딩한 에센셜오일 흡입이 측정시점에 따른 심박변이도와 뇌파의 변화가 혈액형사상체질에 따라 차이가 있는지를 확인하기 위한 반복측정 분산분석 결과, 평균 심박수, 자율신경계 균형도, 상대 알파파에서 에센셜오일 흡입 전후 측정시점에 따른 평균 값의 변화가 혈액형에 따라서 다르게 나타나고 있는 것을 확인하였다. 결론: 페퍼민트 외 4종의 에센셜오일을 블렌딩한 냉성오일 흡입이 자율신경계에 미치는 영향이 개인의 혈 액형사상체질에 따라서 다르게 나타나고 있는 것으로 사료된다.

핵심어: 뇌파, 심박변이도, 에센셜오일, 자율신경계, 혈액형

\section{참고문헌}

류성일, 손영우. 혈액형 유형학 연구에 대한 개관: 사회문화적, 행동과학적 및 생화학적 관점에서. 한국심리학회지: 사회 및 성 격, 21: 27-55, 2007.

전연아, 우나리야. 아로마테라피를 이용한 비만관리효과의 메타분석. 아시안뷰티화장품학술지, 12: 275-281, 2014. 정수현, 임미혜. 로만 카모마일의 흡입이 중년여성의 자율신경계에 미치는 영향. 한국미용학회지, 22: 636-643, 2016. 최은주, 홍선기, 유준상. 아로마 에센셜 오일의 사상체질의학적 분류제목. 사상체질의학회지, 23: 304-317, 2011.

허선희, 유성모. 아로마 에센셜오일의 열성특성에 따른 블렌딩과 인산 혈액형사상체질의 관계. 한국미용학회지, 22: 12361244, 2016. 


\section{中文摘要}

\section{按照血型四象体质群体比较研究精油吸入对自主神经系统影响}

許先姬 ${ }^{1}$, 沈准暎 ${ }^{2}$, 俞誠模 ${ }^{2 *}$

1脑科学香油疗法研究所, 仁川, 韩国

2国际脑教育综合大学院大学脑教育学科, 忠清南道天安市, 韩国

目的：按照血型四象体质群体比较研究精油吸入对自主神经系统影响。方法: 薄荷、迷迭香、桉树、松树、柠檬精油按 12:4:2:1:1的比例混合。以32名中年女性为对象，将纱布浸泡在混合精油中，贴在受试者的劲背28 min。吸入精油前，吸 入精油后立即以及吸入精油后 $4 \mathrm{~min} 、 8 \mathrm{~min} 、 12 \mathrm{~min} 、 16 \mathrm{~min} 、 20 \mathrm{~min} 、 24 \mathrm{~min}$ 分别测量心率变异性和脑电图。结果: 为 确认根据血型四象体质，混合精油吸入随着测定时间心率变异性和脑电图变化是否有差异，进行反复测定并分散分析。 其结果显示，平均脉搏数，自主神经平衡，相对 $\alpha$ 波，在吸入精油前后测定时间的不同，其平均值随着血型有所变化。结 论: 除薄荷以外，4种精油混合的冷性精油的吸入，按照个人的血型四象体质，对自主神经系统产生不同影响。

关键词: 脑波，心率变异性，精油，自主神经系统，血型 